\title{
Institutionalisation of tradition and individualised lived Christian religion in Late Antiquity
}

Eusebius of Caesarea's letter $C P G 3502$ is one of the earliest narratives about the Council of Nicaea (325) that describes procedures and documents used at meetings between bishops and the emperor Constantine. This chapter looks at processes of religious individualisation in the reception of the letter from the fourth to the seventh century and asks which mechanisms of religious pluralisation shaped the transmission of this seminal text for the history of Christianity. It thus questions the context of its twentieth century publication. Analysing also Cyril's letter $C P G$ 5320, the chapter scrutinises the reliability of the narrative implied by the texts that have usually been regarded as sources for the councils of Nicaea and Ephesus (431). It does this by pointing to the processes of religious individualisation that shaped lived Christian faiths and pieties in Late Antiquity. The scope of enforcement of conciliar decisions and the vulnerability of the representativity of the participants will be discussed, situating their actions in the context of the plurality of lived Christian faiths. The chapter also discusses the dynamics of the de-institutionalisation of Roman religious rites in Late Antiquity by examining them in the context of fragmented Christian orthodoxies in which bishops and other religious authorities were vulnerable to accusations, and social upheaval or unrest.

In the vast and ever growing literature about political, religious, and social developments in the fourth-century Roman Empire, anyone reading about the statement of faith of Nicaea, Constantine's involvement in theological matters, Eusebius of Caesarea's Arian inclinations, or related issues is fortunate when the account gives information about relevant fourth-century texts. One of these will probably be Eusebius' so called Epistula ad Caesarienses, CPG 3502. Depending on the target readership of the publication, this information may be followed by a cryptic reference to a recognised modern edition of the work. Most probably, the extremely abbreviated form will lead to 'Urkunden zur Geschichte des Arianischen Streits 318-328, ed. Hans-Georg Opitz, Athanasius Werke 3.1, Berlin/Leipzig: 1934,

\footnotetext{
Note: I am grateful for the input of Geoffrey Greatrex, Markus Vinzent, Jörg Rüpke and the patient readers at Eisenach. This chapter has benefited from the generous support of St Edmund's College. Finally, I thank the University of São Paulo for granting leaves to pursue research abroad out of term and to take part in the conference at which this paper was discussed.
} 
42-7'. This edition is a landmark of conciliar and patristic studies which reflects their harmonising positivistic historical approach to texts. It implicitly created volumes of acta for the synods and councils involving Athanasius and Arius, not least for Nicaea (Brennecke et al. 2007, v-vii; Meier 2011, 125; Brennecke 2011, 15-7; Blaudeau 2012, 139-44, 153; Testa 2014; Stockhausen 2015, 136-42).

From the apparatus of this compilation or the notes in a commentary or a study, the curious reader may learn that the letter was not transmitted as a standalone piece or as part of a collection of Eusebius' letters (which neither he nor any other contemporary or later editor ever assembled). Rather, it was quoted in the works of Athanasius, Gelasius, Socrates, and Theodoret. What the cryptic list of fourth and fifth-century works ${ }^{1}$ does not indicate is that even when significant variants are attested, all the authors were engaging with the text that appears in Athanasius' collection, appended to De decretis Nicenae synodi (Opitz 1935a; Opitz 1935b; Hauschild 1970, 108; Hansen 1995, l). In this work, Athanasius defended his faith and piety by analysing conciliar practice and output, as attested in Scriptures and the memory of the fathers of Nicaea, including, with caveats, Eusebius. The reliability of this foundation was secured by the presentation of written evidence, namely a dossier containing at least a letter. According to the title it bears in Athanasius' dossier, Eusebius had allegedly sent it ahead of his arrival from Nicaea to the people of his diocese. The letter is self-referential and programmatic in character, and some of the rather detailed comments on disciplinary and theological matters addressed at the council are destabilising. Little doubt has been voiced concerning the authenticity of the chronology implied by the rubric in De decretis, which makes the letter 'the most ancient source concerning Nicaea' (Cameron and Hall 1999, 265; Ramelli 2011, 47) and informs the biography of Eusebius' literary persona.

\section{Late-antique religious pluralisation}

The generally accepted picture of the early Church Councils is based not on contemporary documents but, rather, on various narrative sources that have been compiled years, and sometimes many years, after the events they describe. The usual justification for accepting these later sources as evidence is the surrender to their intra- and intertextual claims and narrative guarantees of trustworthiness and accuracy. A long tradition of scholarship on contemporary, or near

1 'Ath. de decr. nic. (BKO R) Sokr. 1.8.35 (MA FHC G $\Sigma$ ) Theod. h. e. 1.12.1 (An s $\zeta$ ) Gel. 2.35.1 (abc) Th.' (OpITZ 1934, 42 ad loc.). 
contemporary, evidence, including studies about Rabbinic culture, Manicheism, Neo-Platonism (and other philosophical lifestyles), magic, Sassanian religion, and North African and Arabic peoples, has not eroded the belief that within a few decades before or after Constantine, if not before, lived Christian religion was an individual position-taking in relation to an institutionalised Christian Church. It is also widely assumed that it can be described with patient Quellenforschung of texts in Greek, Roman, Syriac, Coptic, etc. and the material evidence. The right questions urge rephrasing (Donner 2006).

The textually more prominent late-antique Christianities were self-asserting cultures. Like other late-antique mystical, philosophical, rhetorical, and legal schools, they resorted to textual representations of their past and values, as well as to the performance and narrative problematisation of practices and rituals (Berg 2001, 88-91; Gordon 2015). Within a constellation of discourses of faith, such as statements at synods, or in writings, such as Eusebius' letter, Christian oral and written works were arguments in processes of individualisation for persuasion through identification with religious paradigms and the relative authority of synods (Heil 2010, 87-9, 99f.; DelCogliano 2011a, 672; Radde-Gallwitz 2017; Graumann 2017b, 52). Meanings varied according to the awareness and acknowledgement of biographical narratives and the sayings and writings associated to the authors named for their teaching and in expressions such as 'the faith of the fathers of Nicaea'. Preaching and writing on the logical, (meta-)physical, and ethical notions at stake in the religious polemics was therefore variously understood and interpreted, creating multiple reactions. Especially in communications addressed to larger audiences stemming from a variety of educational and socio-economic backgrounds, concepts and values tended to be homogenised by association to a core (ritualised) vocabulary.

For most late-antique religions, scant evidence exists for the substantial intrareligious diversity or for the common flaring up of violence that occurred when individual or collective expectations about the people or institutions mediating or providing their religious concepts and rites were not met (Hezser 2005; Sizgorich 2009, 21-4, 121-34; Ando 2010; Mayer and Neil 2013; Drake 2013; van Loon 2014, 110f.; Dunn 2015b, 266-8; Kahlos 2015; Dijkstra 2015, 25-30). They are better attested in some Christianities because in these topoi of social and religious individualisation which engaged with Roman imperial values were frequently used. The conscious decision between irreconcilable theological views or against unacceptable misconduct fell between two or more discourses, each of which labelled itself as orthodoxy and orthopraxis and condemned the alternatives as unchristian (pace Otto 2017). Arguments on Christian matters were narratively referred to Roman jurisdiction, insinuating the possibility of imperial involvement in the form of recommendations, promulgation of laws, organisation 
of synods, and invitations to debates. 'Discourses of exclusion' were widespread individual self-assertions of Christian religious identity, whereby self-awareness of belonging to the 'one faith' was expressed by pointing out moral and conceptual dissimilarities to followers of other discourses. Shaping the identity of others excluded these others from the social institution created by the narrative.

It is often assumed that early Christian synods and especially the Church Councils of Late Antiquity reached unanimous decisions which were actively promoted by the participants upon their orderly return. This seems to be corroborated by taking at face-value ancient documents, such as Eusebius of Caesarea's historiographical-theological accounts of the aftermath of the Council of Nicaea, especially De vita Constantini 3.21-2 (Bleckmann and Schneider 2007, 96-101; Johnson 2014, 150f.). Actually, these narratives are part and parcel of the repertory of fragments of discourses created by subsequent authors. This chapter shows their version of the events becoming history, institutionalised by incorporation through quotation and allusion in works and collections written as evidence of the tradition and authority of the fathers, on which many historians still draw uncritically.

The chapter analyses the development of a religious landscape and literary environment which gave shape to a type of epistolography from bishops to their dioceses. It also shaped the social and political meaning intrinsic to these letters, which made them important documents about synodical proceedings and the identity of religious agents. Analysing Athanasius' reception in De decretis of a letter of Eusebius of Caesarea about the meetings at the Council of Nicaea and its statement of faith sheds light on the inclusion of Cyril's letter CPG 5320 in collections of documents about the Council of Ephesus in 431. It shows that the model of a bishop's responsibility for his diocese and accountability to Roman administration, formulated by Eusebius in discourses assigned to the character of Constantine in the letter and in De vita Constantini, is mirrored in the character of his ego-persona and its self-effacing insertion in a collective past there outlined. The existence of the letter posits the fulfilment of this role, lending documentary meaning to the text. Eusebius' process of religious individualisation promotes and defends his faith and piety, that is, his teaching and the uprightness of his character as bishop, teacher and citizen. Athanasius' polemical engagement with it, shaping his ego-discourse and affecting the meaning of Eusebius', shows nevertheless the relevance of Eusebius' writings as well as the religious and narrative polemics associated with Eusebius' persona and œuvre. This step in the reception of Eusebius' discourse is only stabilised in a subsequent moment, represented in this chapter by Cyril's letter $C P G$ 5320. Presupposing the patterns of religious individualisation typified in the literary personae of Eusebius and Athanasius, Cyril's discourse lends them an authority which at that point was not yet simply a given. The rhetorical engage- 
ment with the sacred history of these literary personae and with imperial identity ultimately illuminates the fourth- to sixth-century de-institutionalisation of religious practices and the pluralisation of Christian identities.

\section{A scholar's letter}

Written in the first plural person, Eusebius' letter blurs the boundaries of the views which are ascribed to the synodical bishops, Constantine, and the Eusebius-persona who argues for the acceptability of the emperor's statement of faith (Strutwolf 1999, 53-60; Lieu 2016, 176). The familiarity of Eusebius and the intended recipients with Constantine's Epistula ad Nicomediensis 1-2 (Opitz 1934, 58) should be taken for granted. For the readers of the writings of Eusebius and Athanasius, the existence of a theological discourse in an official public letter from Constantine was much more present and relevant than any hypothetical role Constantine was said to have had in the meetings and theological discussions in Nicaea. The presence of the emperor at the Council of Nicaea established a symbolic link consolidated by narratives and legislation (Noethlichs 2006, 117f.). The literary context which can be associated to Constantine's letters explains the gist of Eusebius' narrative, which uses the character of the emperor to voice a few fulllength theological arguments. The extended account of tensions in the sessions and the details of a synodical controversy seem in line with Constantine's assertions but remain distinctively Eusebius' own.

The letter falls in line with Eusebius' literary creation of Constantine's religious individualisation. Thus, for instance, he credits him with the initiative of assembling an oikoumenikế súnodos, which decades later Philostorgius (Historia ecclesiastica 1.7.7) could still attribute to Athanasius (Chadwick 1972). The elements for the theological argument in CPG 3502 are placed in the mouth of Constantine and a number of bishops in a historiographic narrative along the lines of De vita Constantini and the Historia ecclesiastica. In all of these, Eusebius' emperor is imbued with a theological expertise which needs improvement by the hands of a master, in which role Eusebius paints himself into the narrative. Like De vita Constantini, the 'main point' of the letter CPG 3502 is the prominence assigned to the emperor in the procedures (Higgins 1966, 242). The scene is dialogical, with intervening reference to discussion and debate. This became a leitmotiv of the expectations of emperors about what bishops should do. Sacrae of convocation and reprimand mentioned it, as seen in Theodosius II's missives to the factions assembled in Ephesus in 431. Practices changed little but the discourse of Christians echoed the changes (cf. Graumann 2017a, 271-4). Eusebius 
also created a type for the relation between emperor and bishop in which individual agency and culpability remains with the legislating emperor, while the bishop, although showing greater initiative and theological acumen, subsumes himself into the collective voice of a tradition which is Eusebius' own discursive creation. Demonstrating a collegial behaviour and showcasing the theological correctness, the letter grants Eusebius the qualities which he painstakingly tries to deny his opponents, such as Marcellus (Vinzent and McCarthy Spoerl 2017, 17). His literary and public activities tended towards a coherent authorial persona whose actions and thoughts would be representative of those common to them who, in the eyes of his intended audience, were the faithful and pious (Grafton and Williams 2006; Johnson 2014, 146-52).

In Eusebius' theological works before and after Nicaea, passages such as Demonstratio evangelica 5.1.13 (Heikel 1913, 212, 12-6) and De ecclesiastica theologia 2.14.4 (Klostermann and Hansen 1971, 115) contradict some of Constantine's arguments in $C P G 3502$. Familiarity with Eusebius' claims makes it possible to see that in the letter the character 'Eusebius' harmonises them by proposing a theologically imprecise variant (Strutwolf 1999, 58). Eusebius' statements apparently improve on Constantine's ('subordinationist and unorthodox', Higgins 1966, 242), strengthening them against gnosticising interpretations, but in practice they were equally likely to be misunderstood as sabellianism (Feige 1992, 289; Rizzi 2013).

Twenty-five or thirty years later, Eusebius' version of controversies at the sessions in CPG 3052 was appropriated by Athanasius. His dossier in De decretis conveys a polyphonic landscape of theology, religious leadership and Christian authorship in which his own actions and character are a point of reference. It resembles the first stage of the Collectio Corbeiensis (Dunn 2015a, 188), Sabinus of Heraklea's Synagoge (Hauschild 1970, 107-8), and the anti-Donatist group of seemingly authentic Constantinian documents in Historia ecclesiastica 10.5-7 (Carotenuto 2002, 68-73). Athanasius' editorial craftiness is well known from his handling of the citations of Asterius and George of Laodicea (DelCogliano 2015; Cassin 2015; Kannengiesser 2006; Johnson 2006) and of uncorroborated texts (Gwynn 2007, 74). The organisation of the supporting documentation in De decretis has, however, raised few suspicions. The information about the recipients of the letter in the heading of CPG 3502 is accepted at face-value, except for the description of Eusebius of Caesarea as areianófrōn, which is identified as Athanasius' authorial intervention. The adjective is part of Athanasius' casting of Eusebius as like-minded with Arius (Winkelmann, Pietri and Rondeau 2013, 89). It is also part of the narrative creation of 'Arianism', connecting proponents of alternatives to concepts associated with the fathers of Nicaea to the character and theses excluded from the institution which was, at that time, also being dis- 
cursively defined in the reference to a 'catholic' 'church' as recipient of imperial letters, such as De decretis 38. The association of katholikế to ekklēsía was quickly gaining visibility in Constantine's official discourses, particularly in his letters, universalising it. In Christian polemics, it was simultaneously associated to a qualitative connotation which cast dissident communities as alien to what was officially sanctioned as the only authentic religion and, therefore, the receiver of imperial largesse (Vinzent 1999, 237-40; Winkelmann, Pietri and Rondeau 2013, 373). Athanasius discursively created 'Arianism' as the contrast to the communion with Nicene fathers, imbued with the faith he ascribed them, thereby amalgamating for polemical purposes their plurality of religious practices and interpretations (Gwynn 2010, 233).

Making his model explicit to the reader of De decretis, Athanasius assimilated to his theological argument the rhetorical mise en scène of the 'original', that is, he attributes his interpretation of homooúsios to that of the emperor and his implicit authorial-persona to the role of an instructing interlocutor with emperors previously played by Eusebius. So much for the discourse projected towards the future. Athanasius created a narrative of an 'official' imperially sanctioned understanding of Nicaea where there had never been one before by crafting references and traditions (Boyarin 2000, 27). Eusebius had used a similar rhetoric in his debates, for example that against Marcellus, and CPG 3502 casts 'good' piety and faith in a nutshell. Athanasius created the authority of Eusebius' distinctive account of the Nicene controversial language, while reminding the reader of the limitations in Eusebius' attitude. In the narrative, the letter polemicises against hoi peri Eusebiou, a category which Athanasius associates explicitly to Eusebius of Nicomedia and Eusebius of Caesarea, as well as ambiguously to both or neither, in a number of works, including De decretis and Epistula ad Afros, almost all written after the deaths of both Eusebius (Stockhausen 2002, 194; Morales 2006, 288-90; Gemeinhardt 2011, 210-4; Bergjan 2017, 134). Furthermore, a well-informed reader might know of conflicts between the theology put forward in CPG 3502 and that defended elsewhere by Eusebius. Such contrasts encourage an interpretation of the letter as having a preemptive character, as if Eusebius tried to remain a step ahead of information and rumours about the discrepancy between the synodical decisions and his earlier teaching, or about incidents during the Council in which his orthodoxy had been questioned or situations in which he had committed or suffered anything that might weaken the authority of his discourse.

The heading turns the letter from proof of good citizenship into evidence that Eusebius had sown contention on theological minutiae among the population of the Roman Empire, since he had referred to and given detailed examples of the sort of religious disputation on words used by all factions to decry their critics. The letter would show Eusebius also working against the imperial wish to promote a 
view of Christianity and of the imperially-designed synod of Nicaea as a harmonious gathering of like-minded individuals all in agreement with one another. It described the synod as a process and not as the confirmation of the bishops' agreement on the versions conveyed by synodical letters and in references to the events. Furthermore, Eusebius would have exposed the emperor's religious shortcomings to the recipients which Athanasius in De decretis described as the Caesarean paroikía. Read with the values of fourth-century Christian epistolography in mind, CPG 3502 communicated the intrinsic insufficiency of the Nicene statement of faith and its need of interpretation thereby inducing its pluralisation (Strutwolf 1999, 53).

\subsection{Eusebius' historiographic and panegyrical epistolography}

The narrative coherence of a literary persona and the ideas being put forward by it should not be confused with the sincerity of the author (Ayres 2007; Drake 2014, 43f.; Frenkel 2017). Eusebius' portrayal of, and relation to, Constantine is clearly more ambiguous than a literal reading of his panegyrics might suggest. However, nothing indicates that he fomented public dissent (Johnson 2014, 151). By the time of the Council of Nicaea he had already established a significant authorial presence in the theological and exegetical landscape with which the letter is in dialogue and in which its direct or indirect readership placed it. Eusebius had inherited a multi-faceted role from Origen via Pamphilus and the school which he seems to have kept active also in Caesarea reflected this (Zamagni 2011, 158-73). The literary 'I' that Eusebius set out defended the interests of this milieu, stamped with imperial endorsement of its editorial output by the imperial letter exhibited in De vita Constantini 4.36, but also by the characterisation of Eusebius' persona and his rhetoric as expert advisor and interlocutor, as seen in CPG 3502. It should furthermore be plausible that this literary 'I' was the 'same' of Eusebius' persona in the Commentary to Isaiah, and De ecclesiastica theologia, for example (McCarthy Spoerl 2006, 41; DelCogliano 2011b, 41-5; Inowlocki 2011, 199; Penland 2013; Johnson 2014, 42-6, 144f.). His narratives of pastoral concern show that he tended the reputation of his authorial voice for the sake of the ongoing recognition of the validity of his teaching. They illustrate how in the empire projected by his historiography, erudition was a vital asset.

The narrative statement of Eusebius' zeal for the correctness of faith and piety according to Nicene and imperial decisions updated his authorial persona. Retrospectively plausible, the story neither indicates that he altered his view or that he endeavoured to actually spread the concepts and instructions mentioned in his historiography of conciliar organisation and authority. Eusebius did not dispute 
the authority of the Council of Nicaea. Accordingly, he recognised the validity of the statement of faith on which the members had agreed as a suitable formulation for the issues discussed there. Nevertheless, he took for granted that bishops were entitled to articulate in other creeds the orthodoxy they claimed to share, and to try to convince their peers that they expressed the same faith (Campenhausen 1976, 128, cf. Kinzig 2017, 306, 317). When Eusebius affirmed the historiographical relevance of Nicaea for the characterisation of the empire and its relation to Christianity, the event did not yet have the religious referential character which Athanasius attributed to the faith of the fathers of Nicaea in later writings. Complemented by other authoritative sources, it became a yardstick that had to be verbalised as suited the time and the problem at stake (Stockhausen 2002, 2).

The performance of a letter conveyed the voice of the writer and letters addressed to just a few recipients were tailored to them specifically by the choice and arrangement of the arguments. Thus, detailed lines of reasoning should have been envisaged for small expert audiences. The letter-writer assigned them characteristics which may have overlapped or even corresponded to their actual identity. As shown in Higgins' recreation/paraphrase, Eusebius characterised himself less as a bishop who had the responsibility and entitlement to instruct on faith and piety (Bowes 2007; Elm 2015, 93, 99-105) than as a master/teacher and Roman citizen who engaged in disputations with non-Christians. Casting Eusebius' authorial voice as that of an irreproachable citizen, CPG 3502 seems to address expert readers who could be beyond the confines of Christian positions. The account of the Council of Nicaea in Eusebius' letter is centred on the agency and synodical authority of an unbaptised emperor. As in De vita Constantini, the narrative focus has a biographical and panegyrical character (hypothetically) addressed to the emperor and aiming for a broad readership (Barnes 2007). Accordingly, Eusebius did not expect the recipients to know the wording of the statement of faith, which is a paradox if the rubric is assumed to be true (Campenhausen 1976, 129f.). The letter is a defense of Eusebius' persona in terms relevant to Roman legal and administrative procedures, not to his spiritual authority as bishop. Suggesting that Constantine was persuaded by his exposition of the Nicene statement of faith, Eusebius' letter claims that complaints, petitions and civic measures moved by or under the instigation of his opponents, even if they were the majority of the bishops or a synodical consensus, would be going against the imperial will and wish. In both De vita Constantini and the letter, synodical decision-making is subordinated to the pronouncements of a non-Christian, sidelining the relevance of the consensus among the majority of bishops who were disputing at that time the soundness of Eusebius' teaching. In De vita Constantini, Historia ecclesiastica and CPG 3502, Eusebius was knowingly adding a narrative to a tabula rasa of content and styles, not because 
no socially recognised patterns or works portraying the relation of bishops to emperors or synodical proceedings existed but because proceedings varied and were often contentious and none of the available narratives had gained status. They present exemplary life patterns for inhabitants and officers of an empire ruled by a Christian emperor. As panegyrics, De vita Constantini and CPG 3502 are naturally silent on Constantine's failures, especially on matters of faith, and compatible with his administration and legislation, which both favoured other groups and circumscribed Christian practices. They were part of a religious landscape characterised by dynamic pluralisation, not least by the superimposition of family traditions, education in lifestyle-informing schools, and regional religious institutions, as well as the changes that took place in each (Belayche 2013, 243; Humfress 2014, 22-9; Gordon in this publication). Reference to, and especially any digression on, the causes and characters who were involved in ongoing religious disputations and growing estrangements would denigrate actions of the laudandus.

The narrative of $C P G 3502$ provides an example of a letter that contributes to the acceptability of the bishop's literary persona (on which depended also the reputations of those on whom he relied explicitly as authorities). Once accepted, this persona supersedes any images that may have arisen from rumours about him having been or become Nicene, which is therefore also of marginal relevance for the individualising effect the letter had. Eusebius' letter shows that statements of faith were dynamic discourses that offered public testimony of religious concepts and exposed the author to their refutation and condemnation but also to reception and interpretation. In these processes, the words which could be used to express the standard of orthodoxy shifted as quickly as in other scholarly engagements with religious notions (Abramowski 1982; Feige 1992, 290f.; Drecoll 2011, 470).

From a certain moment onwards, Eusebius' letter and his interpretation of the Nicene faith were deemed orthodox. His Christian historiography and his conciliar account were the winning narrative models, reinforced in the works of his continuators, late-antique chroniclers, Byzantine librarians, and, finally, the reception of his words at face-value in medieval history, modern history, and church history. The success of Eusebius' strategy is largely due to a (reasonably) independent ratification from an authorial voice which, despite a number of obstacles, gained great authority, namely that of Athanasius (Graumann 2002, 415-8; Graumann 2003a).

Athanasius shaped the context of the letter with his narrative, affirming, with caveats, Eusebius' orthodoxy. Attempts to identify the influence of Athanasius on the apprehension of CPG 3502 effectively lead to circular arguments since all of its reception is apparently dependant of its transmission in Atha- 
nasius' works. The text of CPG 3502 now found in Socrates Scholasticus has several different readings to those available in the extant sources for Athanasius' works, although Socrates drew on De synodis at the time he was revising the first two books of his Historia ecclesiastica and included Eusebius' letter (Hauschild 1970, 108; Hansen 1995, 1). The reader knows of no 'Eusebius' but the 'I' of the narratives which reach him in rumours, texts and discourses attributed to, speaking about, or alluding to Eusebius (pace Lieu 2016, 175). This authorial self-fashioning had to stand up to the scrutiny of the audience, which might be familiar with any subset of the true or invented information about his character, whether real or literary and of his own making or not. The endeavour to memorialise the past occurred in the elaboration of the ego-discourse and the moulding of dossiers and florilegia.

Eusebius' letters were only transmitted within other works by himself or other authors. If, on the one hand, they yield a biased picture of his epistolographic self-fashioning, on the other, the mediated transmission was decisive for the credibility of Eusebius' account. Thus, the letters on creeds present a theological expert as he instructs the recipient with the narrative of engagement with quoted statements of faith and further arguments. Also the transmission of fragments of a letter to Euphration of Balanea (Apamea/Syria Secunda) was mediated by Athanasius as an explanation of Arian concepts (De synodis 17.3). His often vague references to Eusebius' letters do not imply that readers would be able to identify the text from which he drew an excerpt or allusion, nor that he expected or feared that they would have access to his or others' recensions of them. Even De decretis circulated without several or all items of the dossier (Heil 1999, 20f.).

Eusebius' and Athanasius' self-effacing self-fashioning and the weak links to the 'historical truth' of the texts do not belittle their importance. Rather they show the success of the texts in 'becoming true' beyond the scope of their contents and the control of the authors. The targeted audience was aware of the apologetic aim of the writings and engaged critically with them, to improve, appropriate, or refute them. Eusebius' De vita Constantini, Historia ecclesiastica, and letter were the entextualisation of his literary persona, and key elements in the textualisation of Constantine's participation in Nicaea. They also provided a type for synodical proceedings. Athanasius' dossier and especially the Epistula ad Afros operated the recontextualisation of the letter and, by the changing characterisation of 'Eusebius', effected the textualisation of his literary persona (Oesterreicher 2013, 142f.; Humfress 2014, 17; Morales 2017, 70). Later, Eusebius' letter was recognised as an accurate source for the events at Nicaea and for Eusebius' participation in the council, complementing the information in the Historia ecclesiastica and De vita Constantini (Quiroga Puertas 2015, 113f.). 


\section{Individualisation of narratives of religious institutionalisation}

The received view of a homogeneous church, as attested in the literature and in figures of speech, did not correspond to the multiple forms of religiosity that can be deduced from the same texts and appear in the textual and archaeological evidence (Belayche 2013, 243). The late-antique religious landscape went through a fragmentation of authority due to the existence of conflicting discourses about the same religious referential, namely, the individual identity as Christian. Despite the proliferation of texts claiming normative value in their internal narrative, lived Christian religion remained a multiplicity of experiences, varying from the level of the individual to that of group and society (Rüpke in this publication; Gordon in this publication).

The jurisdiction and spiritual authority of bishops in all areas of the Roman Empire was not uniformly accepted. The normative and institutionalising discourses of regional power over, for example, the control of the see of Alexandria over Egypt and neighbouring provinces co-existed with tokens of individualisation in religious practices and notions. The development of Origenism, monastic and ascetic practices, and messianic narratives were further tokens of individualisation that contributed to the fragmentation in the landscape of monotheistic religions in Late Antiquity. In the later fifth century, narratives exposed the ongoing vulnerability of the bishops of Alexandria when they were unable to handle challenges or gain credibility for their narratives. The powerful bishops of the fourth and early fifth century were also threatened but the limitations of their control are hardly evident in the sources (Martin 1997, 173; Gemeinhardt 2011, 335-43; Gwynn 2013, 50; Wipszycka 2015, 135, 314-35). A living memory remained of the endorsement of the synodical depositions of controversial figures such as John Chrysostom, Athanasius, and Eusebius, and of imperial support for disputed views, including Arian, Eusebian, and Sabellian concepts. The cultural contacts between Christian and local cultures, such as the pre-Islamic tribes, also show the resilience of beliefs in the face of preaching and legislation (Shepardson 2008, 25-46; Millar 2009, 104). Stereotypes were reinforced by normative discourses and fuelled accounts of tensions which flared up during episcopal elections, controversies, and when bishops were vulnerable and displayed weakness (Crawford 2013, 253-7; Kristensen 2016). These social processes informed features of oral discourse reflected in narrative patterns, such as acclamations and the historiography of social unrest (Rammelt 2013; Piepenbrink 2014). More than processes of religious individualisation, they reflect late-antique mechanisms of reaction to representative bodies and nominated leadership. In this context, the authority 
of elected post-holders or bodies and of endorsed leaders, such as bishops and emperors, existed only as long as it met public expectations. Their grip on power was intrinsically vulnerable (Humphries 2015; Kaldellis 2015, 147-50).

Local reaction to news about the depositions of bishops and about new appointments suggest that information concerning synodical events could spread quickly through oral and written narratives. These could range from assumptions, rumours, and calumnies to announcements supported by material evidence. The information would not reach everyone in all dioceses equally. The title Eusebius' letter CPG 3502 bears in Athanasius' dossier places it in this context. A pastoral letter should dispel rumours and calumny and restore the respect, confidence, and familiarity of the people. It should help to create a more homogeneous and receptive audience for the bishop, handling the expectations his engagement had created, possibly by his own instigation. Several narratives describe the risks bishops who left their dioceses might run when they returned there (Flower 2013, 156-62; Hillner 2015, 249-55). They might face an adverse reception, either because during their absence significant parts of the clergy or the people had risen up against them, or because they came back spreading an unwelcome discourse. The diverse social, religious, and educational background made the people in a diocese a locus for widespread individualisation. As with most classical narrative topoi, this story combines and modifies factual details of several moments and places that are part of the shared narrative culture. In this case, the story implies that it was incumbent on a bishop to coalesce his public somewhat so that those who thought of themselves as Christians, and had therefore their notion of 'we' (Christians) vs. others, did not disagree with him on the matter at hand. This dynamic of the performance of a letter sent to a diocese makes it plausible that Eusebius and Cyril wrote to their dioceses but gives no guarantee that the literary versions transmitted in the compilations were once de facto letters.

\subsection{A letter to a diocese}

The narrative setting derived from the rubric of Eusebius' letter shows him looking after interests that were his responsibility. It does this by asserting that he had engaged on behalf of the faith on which everyone in his school, in the diocese of Caesarea, and in the kósmos agreed until then. This he had laid out in his personal statement of faith. The narrative presents him showing to all in Church and Empire the compatibility of his and the Nicene faith. In the Christian oikouménē and the Roman kósmos, a bishop was responsible for his diocese insofar as it expected him to look after its interests and he bore responsibility for 
what happened in it. At a synod, or in front of civic and imperial authorities, a bishop was a representative of the collective will of the people of his diocese, who ought to defend the interests of his see, therefore of the metropolis and thus of the city as well.

Most synods would issue synodical letters addressed to all dioceses but the chain of dissemination and enforcement of synodal communications was multi-channelled. Like governors, bishops entrusted with writings might not disclose them in their territories and communication of actions was contingent on local interests (Corcoran 2000, 245-53; Weckwerth 2010, 22; Allen and Neil 2013, 18-33). Subscribers to synodical decisions ought to abide by the decisions. In CPG 3502, Eusebius has Constantine and his ego-character echo the expectations that bishops should teach and foster the faith and piety. The rubric endows Eusebius' letter with a narrative of preparing the ground for his return, which suggests his commitment to putting into practice what the Historia ecclesiastica describes Constantine exhorting the bishops to do. To stop the promotion of topics condemned by synodical or imperial promulgations could also be expected, according to the common topos of episcopal diatribe of denouncing failures to do so. Bishops could be accused of neglecting their office if condemned practices, beliefs, and the teachers of such were identified in their dioceses (Crawford 2013, 237-40; Schor 2015a, 162-9).

Eusebius' letter claims it suffices to follow his pre-conciliar teachings. It lays out the compatibility of his private statement of faith and of the statement agreed on by every member of the Council. It exempts from any accusation his former doings and everyone who acknowledges them, even if they ignore the faith of the fathers of Nicaea. Casting the recipients as Eusebius' paroikia, the rubric presents Eusebius as proposing the creed and its explanation in the guise of bishop of Caesarea, that is, in the name of his diocese and, thus, of each Christian in it. It is an attemporal and universal representation of the faith and piety of the members of the church of Caesarea. There was, then, no need to alter or to actively promote the theological import of the Nicene faith. The writing guarantees that the Christians in Caesarea agree on either Eusebius' statement of faith or on that of Nicaea. Failure to do either befell then not the collective dimension of the diocese, but individual lived religion. It was not enough to accuse a bishop of the transgressions of members of his diocese if it could not be shown that he was somehow responsible for it. Eusebius' letter prevents any such accusation: he had an orthodox diocese and he was an orthodox bishop; any deviation thus had to originate either from outside forces or from faults of individual Christians.

This representation of a bishops' accountability for the homogeneity of the Christian faith in his diocese was relevant for Athanasius in view of imperial concern with the violence he and other Christian groups were deploying in Egypt. 
The internal narrative in Athanasius' use of Eusebius' letter acknowledges the accusations that Eusebius was not Nicene ahead of the Council but blurs them, too, by endowing him and the theological content of the letter with positive qualifiers. It suggests that Eusebius could dispel the accusations by preparing a writing on the statement of faith of his diocese, which is also the theme of the work of Athanasius in which it is cited. Athanasius' rubric connects CPG 3502 to the task which, according to the historiographic narratives of Eusebius and Athanasius, Constantine gave the synodical bishops. In short, numerous processes of religious individualisation discussed as possible scenarios for the composition and primary reception of Eusebius' letter qua literature, qua private letter or qua letter to his paroikía probably occurred at his time but were not recontextualised and transmitted. Moreover, the processes that actually happened cannot be reconstructed accurately for any text, even when supported by plenty of details about its later reception, because it does not yield enough data. The text conveys only one key piece of information: Eusebius deliberately projected an ego-discourse into history that situates himself viz. the rulers of a wider religious landscape, which he depicted across his oeuvre. In his narrative creation, he obscured his agency by projecting himself into the reception of the past - a past created by his discourse which modifies the past conceived by the reader. Eusebius' ego-discourse was relevant for Athanasius as a precedent for advancing antiquity over majority, so that a hardly attested Synod of Rome would rank higher than the historical Synod of Antioch (Abramowski 1982, 263; Vinzent 1999, 388).

\section{Eusebius' many letters}

Although in Athanasius' (extant) writings CPG 3502 is only quoted in full in the florilegium in De decretis, he referred to or quoted from it in a number of other works as well. Some came from his later years when he was no longer antagonising Eusebius downright, in part through a selective appropriation of his literary output. If in the dossier the heading denounces the theological problems of the letter and casts the author as non-catholic, in the main text Athanasius offers little criticism of the letter itself (Ayres 2004, 352-5). That is, once it is 'improved'. Athanasius' arguments not only resemble their theological content, which is standard fourth-century fare, but also develop, respectively, the character of and relation to past and present authorities with similar rhetorical strategies. Reliance on Eusebius' authorship and epistolary voice goes so far as to leave implicit in De decretis 3 an argument stated in full in CPG 3502 about the dual function of the term 'from God', which serves to distinguish the Son from the creatures and to 
demonstrate that the Son is from the Father (Ayres 2004, 353). However, when the metatext is not so obvious, as in De decretis 19 and De Synodis 4, the reasoning is restated. The similarity coexists with the disparity between the webs of reference for the terms the two authors are defining to use as ciphers. This is to say that concepts such as homooúsios inherit different meanings from the narratives and the authorial voice associated with them. Athanasius' confrontation with Eusebius' reputation and with the theological content of the letter are clearly derived from a scholarly engagement with the text that makes it likely that he worked on his own copy of the dossier, much like Sabinus assembled his Synagoge and Maximinus wrote scholia on Parisinus Graecus 8907 (Hauschild 1970, 124; McLynn 1996; Testa 2013).

Athanasius' recourse to Eusebius' writings on the faith of the fathers of Nicaea, in particular to his creedal formulations varied. It did not follow any clear pattern or development, as can be seen focusing on his major apologetic writings. He attached CPG 3502 to De decretis and described it as Eusebius' letter to his paroikía. In De synodis, which is considered a reworked and more polished improved version of $\mathrm{De}$ decretis, Athanasius referred to two different creedal statements by Eusebius. For one, he mentioned the creed found in CPG 3502 without identifying the source and, when referring to the letter, he did not specify to whom Eusebius wrote it. Athanasius furthermore referred to the statement of faith in Eusebius' letter to Euphration of Balanea. Finally, in the Epistula ad Afros, Athanasius mentioned CPG 3502, describing it as Eusebius' letter to 'the same' which, in the context, might refer to a number of possible addressees but hardly to his paroikía. A reader of Epistula ad Afros who lacked access to texts such as those appended to De decretis was more likely to see in it a reference to Eusebius' school or more probably his sympathisers, the Eusebians, whom Athanasius was combatting (cf. Ad Afros 7.1). Athanasius furthermore included Eusebius on the list of fathers in Epistula ad Afros, while he had previously left Eusebius out of the analogous list in De decretis 25ff. and tarnished his name in the rubric of $D e$ decretis 33, only praising his parádoxon in the course of the theological argument of De decretis 3 (Stockhausen 2002, 50).

Eusebius projected in the ego-discourse, as well as in Constantine's sayings, an image of an 'intellectual' Christianity for which texts, exegesis, and instruction seem central. His contemporaries sometimes reacted negatively to this representation. Athanasius' irony about Eusebius' links to lógioi in Epistula ad Afros 6.4 is a case in point. Eusebius' partial depiction of the religious landscape remained controversial. For Socrates (Historia ecclesiastica 1.1.3), Eusebius' sermo humilis was not convincing and cast a shadow over the accuracy of his views (Wallraff 1997, 235-57; van Nuffelen 2004, 173-87; Bouffartigue, Martin and Canivet 2006, 40f.; Quiroga Puertas 2015, 111; Young-Evans 2016, 19). 
Fourth- and fifth-century writers, especially Gelasius (Verdoner 2011, 6-7 on De decretis 4.4 and 5), still cast Eusebius in with the 'Arians', who are presented as insidious and contentious, propagating accounts that weaken the solidity and certainty of (imperial) institutions and of statements about faith. This echoed a negative characterisation of Eusebius' contribution to the Council of Nicaea and of his theological inconsistency, reflected in Athanasius' rubric. Nevertheless, they also qualify Christianity, Empire, their relation, and their members according to lines which were to be found in Constantine's official letters and had been used by Eusebius. This resonates in Athanasius' suggestion that Eusebius' works were known and were becoming the sources for later authors.

This overview of the reception and spread of these works in Late Antiquity and Byzantium, offers a very different picture of the impact of Athanasius' writings on the reception of Eusebius' letter and reputation than the incautious modern reader would gain from the apparatus of Opitz 1934, ad loc. There, the anteriority and the presence of the 'whole' text give De decretis a status it never had. De synodis succeeded in superseding De decretis and both works were less copied and cited than Epistula ad Afros. This can be seen in the following summary of the secondary transmission of Athanasius' works, limited to a list of the authors, regardless of their religious or geographic status (cf. Brennecke, Heil and Stockhausen 2006, lxxvii-lxxxiii; Heil 1999, 8-21):

1. De decretis: catena in Epistulam ad Hebraeos (Cod. Parisinus gr. 238); Severus of Antioch;

2. De synodis: Socrates Scholasticus; Severus of Antioch; Euthymius Zygabenus; Doctrina patrum;

3. Epistula ad Afros: Theodoret; Severus of Antioch; Timothy Aelurus; Leontius of Byzanz; Eulogios and a Syriac translation.

This list shows the limited engagement with De decretis, which would have contributed to the reduced availability of this texts and its dossier. At the same time, the quotation in Theodoret's Historia ecclesiastica (with the mention of it being a letter 'to the same') and the Syriac translation indicate a preference among fifth- to eighth-century authors for the Epistula ad Afros, which contrasts with the invisibility of the text for almost a hundred years, one of the points used to argue against its authenticity (Stockhausen 2002, 27-32). Thus, the information about Eusebius' letter and its narrative was received primarily under the bias of Epistula ad Afros. Furthermore, positive characterisation of Eusebius is more frequent in the $b$-type ('Antiochene' in Opitz 1934; Opitz 1935c, 98-104) transmission of Athanasius, which predominates in the extant manuscripts (Tetz et al. 1996, 18; Heil 1999, 3-8). 


\section{A bishop's letter}

Eusebius' appropriation of authority by claims of filiation to a number of characters would have evoked the characteristics of ego-discourses in biographic and historiographic works familiar to his public. Despite ancient and modern attempts to identify the genealogies of authority to which Eusebius referred in De decretis 33.13, such as the glossator of Socrates' Historia ecclesiastica 1.8.51, it is their very ambiguity that allows Eusebius' ego-discourse to appropriate information about experiences of religious individualisation known to his reader. Indeed, it is possible he conflated this information with the reader's awareness of Eusebius' narratives of people and events in De vita Constantini, Historia ecclesiastica and treatises. This argument of filiation moves into focus in the later works in which were received texts by Eusebius linked to his involvement in the events of, and controversies surrounding, the Council of Nicaea. Athanasius' writings which point to $C P G 3502$ and other letters by Eusebius are a seminal case in point. Patristic filiation is not only expressed in the text (for example in De decretis 25.1) but also underscored by the quotation of a passage of $C P G 3502$ as Eusebius 'steadfast' addressing 'his own', which later many translators have paraphrased as his paroikía from the vantage point of our access to the late-ancient texts.

The reception of the literary personae of Eusebius and Athanasius further shaped the processes of Christian individualisation and institutionalisation. Eusebius' topoi of moral and theological accountability viz. expectations associated with the Roman emperor resonate in the redaction and edition of synodical proceedings and supporting documents. However, the perception and expectations concerning the letters a bishop might send to his diocese while away at a synod or ahead of his return were decisively shaped by Cyril's letters and treatises. The modern, largely unquestioning, acceptance of the trustworthiness of the information in the heading of CPG 3502 given by Athanasius in De decretis 33 was preconditioned by the inclusion of pastoral letters by Cyril in edited works about later events, especially in the acta of Ephesus 431. A case in point is the influence the Epistulae ad clerum populumque Alexandrinum, CPG 5320 and 5321, (ed. Schwartz 1914ff. I I/1, 116f.) have on the characterisation of the main religious and political agents and the interpretation of texts and events mentioned elsewhere in the collections of conciliar documents. The discovery of a cameo of daily life in the synodical collections may surprise the modern reader. The text in the modern editions of Acta conciliorum oecumenicorum is, however, part of the editor's narrative creation of Cyril's good character, governance, and episcopacy. The agency of the ego-character fades into its narrative of past or unnamed actors who give no clue about Cyril's contested situation. The difference between the depth of the theological exposition of the letters of Eusebius and Cyril parallel the 
diverging views on erudition and education which Eusebius assigns to Constantine, and for which Socrates Scholasticus faulted Eusebius' Historia ecclesiastica.

Few aspects of late-antique synodical and imperial literature have received so much attention in the current source-critical scholarship than the flaring up of the Nestorian controversy and the June 431 Cyrillian session. They paraphrase and harmonise the texts to create further convincingly plausible accounts, which remain hypothetical (Fraisse-Coué 1995; Graumann 2002, 357-98; Barnes 2011, 121-7; Frenkel 2015; Amirav 2015; Bevan 2016). Unlike the abundance of theological arguments in Eusebius' CPG 3502, Cyril's letters seem to dwell on mundane matters interspersed with common-sense exhortations expressed as Christian admonishments adorned with Scriptural quotations. Cyril's letter to the 'people' of Alexandria supports the trustworthiness of the synodical historiography conveyed by the compilation and the uprightness of the characters within. Albeit filled with plausible minutiae from travel literature, the letter rehashes formulae which could serve as a reminder of who the bishop was, that he was alive, and that, in his view, he was still in control of the see. It would counter tentative usurpers and be written proof to disqualify the authenticity or authority of reports and documents announcing his deposition, even if they were true. For those who recognised the authority of Cyril's narrative persona, the writing would void any later rumours or disqualify measures and actions such as Theodosius II's later acceptance of the conciliar decision to depose Cyril.

The historical and narrative context in which developed the relevance of literary engagement with oral or written discourses of earlier authors and the sanctioning of narrative patterns which led to the initial redaction of acta of Ephesus is convoluted. It was influenced by the later Cyrilian sessions, the imperial endorsement of the decisions of the sessions of the so-called Oriental bishops whose contacts with the Roman administration were far less murky than Cyril's, his own deposition and imprisonment, and the little understood events in Chalcedon and Constantinople where, with the direct involvement of Theodosius II, the synod was finally dissolved. The Cyrillian synodical documentation does not acknowledge any insufficiency in the ecumenicity of its conciliar proceedings, nor the validity of the proceedings and decisions of other groups of bishops. The reader of acta, however, would be aware of the physical and intellectual ridicule of Nestorius, the Orientals, and other recognisable narrative personae associated to deviating practices or beliefs. Invective concerning moral and theological shortcomings was a common tool to dissuade the internal and real audiences from incurring or persevering in disciplinary or theological heresy. 'Mere rhetoric' contributed to stabilise and give cohesion to ancient empires, especially the late-antique Roman empire (Diefenbach 2012, 64-9; Wienand 2012, 163-75; Pfeilschifter 2013, 330f.; Humfress 2013, 84-92; Mattheis 2014; Börm 2015, 18f.). 
Perhaps, for Roman taxation and legislation, enforcement of imperial measures was more relevant than the social effect of the rhetorical didactic trope found in their narratives, which informed the Roman imperial identity of the ruler stylised as a pater familias. However, in general formal announcements and physical violence alone did not alter the faith and piety of Roman audiences, as reflected in discoureses about Christianity. Cyril's narrative oriented the Alexandrians towards a Christian way of life purged of what was incompatible with it, including even rulings of synods on orthopraxis and jurisdiction.

The rhetoric of the letter CPG 5320 (cf. CPG 5321), including the images of storm, care, and concern, contributes to the narrative context of the minutes and synodical letters the strength and unassailability of its leading character. This contrasts with Cyril's vulnerability in the narrative found in imperial legal documentation, which recognised the condemnation of those presiding over the synods (Cyril, Memnon and Nestorius) but not of their followers or of the subscribers. This was a legal and imperial narrative circulating independently of Cyrillian literature and a piece of material evidence that could be used as a precedent for future accusations. The reader, commentator or scrutiniser of the acta and of collections of Cyril's letters who reads-over-the-shoulder of the people of Alexandria sees Cyril's concern for his diocese. He also interprets anew images of storm and navigation, which were topoi for the Roman state and its relation to Christianity too.

The soft and most gentle winds of Cyril's crossing of the great and wide sea echo his participation in the synodical sessions. Cyril is a passenger and no reference is made to crew or captain, just as the minutes of the session craft the impression that the proceedings unfolded autonomously, without leadership or any organisation standing in the wings. Nothing hints at the shortcomings, suffering, and illness which wreaked havoc on the preparations, nor at the violence employed by Memnon's imperial soldiers, just as the Cyrilian documentation is silent about the existence of meetings by a group of bishops who likewise considered themselves to be the Council of Ephesus. The letter documented Cyril's serene punctuality, which was a counterpoint to the prolonged delay of the Oriental bishops. Belittling this, the letter addressed the criticism waged against the Cyrilian sessions for having happened without waiting for the arrival of all, since all should participate in the synodical session. The representation of a relatively harmonious unfolding of the Council of Ephesus given by CPG 5320 and other conciliar documents contributed to the characterisation of synodical collections as more authoritative than imperial compilations, such as the legal codes.

Cyril's works conferred authority on Athanasius' literary persona, affirming the reliability of the content of Athanasius' works (for example, the representation of Eusebius as an orthodox and good bishop). Eusebius, seen through 
Athanasius' discourses, which were, in turn, endorsed by Cyril's narrative persona, is the reference for Cyril's orthodoxy and for synodical historiography. Alongside the conciliar sermons of Theodotus of Ancyra and Acacius of Melitene, the letter contributed to equate Cyril with Athanasius and, especially, with Eusebius, that earlier great New and Old Testament commentator, major letter writer, keen interlocutor with the administration, and meddler at court. Praising Cyril's interpretation and appropriation of the past, the narratives endorse the authority of his discourse, which exhorts the reader to adopt his model of individualised lived religion (Graumann 2009, 39). Since Cyril seems to make use of the Fathers correctly, his doing what Eusebius did in writing a letter to his diocese when travelling because of a synod as a token of pastoral concern would have the same effect as a textual guarantee of orthopraxis and creedal orthodoxy, according to Athanasius, whom Cyril lays out as an authority.

The validity of this process of religious individualisation depended of the social endorsement of circular arguments which gave historiographical accuracy to narratives, by accepting that texts which owed their existence to them, as citations and allusions, and around which the works had been composed, corroborated them. Similar processes of religious individualisation involving inter alia imperial and Christian narratives increased the pluralisation of Christian identities in the Roman Empire. The rhetoric of self-assertion by exclusion of others fostered the rejection of non-orthodox rule. However, the late-antique rulers whose faith was not considered orthodox by parts of the population conflicted with the prevailing concepts of rulership, still influenced by Roman republican and imperial narratives which informed the ongoing, albeit modified, imperial cult. Athanasius' contemporaries, for example, had living memory of pre-Nicene, Arian, and Nicene emperors. Historiography and hagiography monumentalised examples of Christian self-assertion viz. Roman emperors. The conscious decision in support of religious heterodoxy or heteropraxis, unrealisable in the first centuries, started to become an option in the period leading up to Justinian's reign in the East as well as in Western kingdoms and dioceses, when normative and legislative definitions of heresy gained visibility in discourses, praxis, and legislation (Meeder 2015, 104f.; Dunn 2015b, 282-5; McKitterick 2016, 255-8). The processes of institutionalisation in Latin, Byzantine, Syriac, Jewish, and Arabic traditions countered this with the endorsement of the truthvalue of certain narratives that were warranted by reciprocal corroboration and their reception in late-antique antiquarianism. Gradual validation of reading these ancient texts at face-value made real the concepts of a well-defined institutionalised Christianity, the events and characterisation of individuals, their agency and individualisation, and the antiquity and tradition of the theological ideas presented in the text. 
It seems obvious to the incautious curious contemporary reader with whom the chapter began that a Christian leader should act and speak of his initiative self-deprecatingly and let his conciliar activity be subsumed in a collective voice. Athanasius' use of Eusebius' letter is typical of fourth-century intranarrative processes of individualisation. The admonishments and concepts of semiotics and communication in meta-literary and programmatic works were strategies to cope with living memory and existing textual evidence of former views, without having to acknowledge and reject them openly (Stroumsa 2016). The status of Eusebius' rhetoric was shaped by the selective reception of Athanasius in Cyril, Socrates, Ephrem, Theodoret, Maximus, Rufinus, Jerome, Gregory etc., who engaged with Athanasius' narratives much as he had with those of Eusebius. The tendency to present Christian polemics and synodical 'solutions' in the terms and conditions of imperial identity, focusing on unity and the avoidance of stasis had, in Eusebius' CPG 3502, a relevant vade mecum to represent dialoguing with an emperor and improving his opinions.

\section{Concluding remarks}

The chapter has focused on oral and written discourses of fourth- and fifth-century bishops addressed to a synod or to their dioceses in which they defended their participation, their stance towards its collective decision, and legitimacy. Allegedly arguing for the interests of the people and properties of a bishop's see, the discourses present agonistic and cohering processes of Christian individualisation, respectively by the exclusion of deviant beliefs and behaviours and by the conscious assimilation of the faith. They reveal the diversity of apprehensions of the numinous even when promoting a de-individualising engagement within Christian faith. Thus, what seem to be homogenising decision-making and communication processes actually attest the spread of patterns of self-practice superimposed on Roman and regional individualised customs, countering the idea that pre-modern religions are collective phenomena. The discourses reveal the diverse cultural and metaphysical concepts that shaped Christian appropriations of religious agency, insofar as the relevance of the arguments depended on education, profession, and engagement in religious life. The texts and discourses which seem to be proof of an enforcement of homogeneity were apologetic writings which advocated at their inception for a range of moral, ethical, cultural, political, and metaphysical behaviours or beliefs, and participation in rituals and adoption of observances with which individual practices and social spaces should not be incompatible. 
Narratives related to synodical decisions were a prominent agent of change in the fourth- to seventh-century legal pluralism of the Roman Empire and bishops were vulnerable to them. The material or textual evidence of effective enforcement of synodical decisions is rather scarce. At first sight, the supporting texts of conciliar documentation, such as letters and homilies, seem to be witnesses of processes of institutionalisation. Their making, however, reflects individual narrative institutionalisations of the past in the form of an appropriation of available narratives which modifies the past and makes it available for individual engagement with the religious beliefs and practices. Editorial interventions consolidated written evidence for the defence and construction of authority or for its disavowal. The narrative 'institutionalisation' seen in legal, historiographical, and religious accounts and compilations proposed textual landmarks which contributed discourses with inbuilt claims of authority as 'historical documents'. They construed traditions about the authors as 'fathers' and consolidated religious, behavioural, and theological arguments and historiographic content anchored in the authority of the literary persona or the repository of the collection. Showing Eusebius' pastoral concern, the rubric in Athanasius and Socrates effectively makes him into the first of the pateres ekklêsiastikoi (church fathers) according to the criteria which he had laid out in Contra Marcellum, in what amounts to the first occurrence of the expression, spontaneously used in the argumentation about the relevance of earlier authors (Graumann 2003b, 883-7).

Eusebius' letter was preserved and gained its historiographical status by a process of religious individualisation through Athanasius' selective appropriation of earlier narratives, sometimes inserting them as written proof in his text, but not necessarily verbatim and possibly adding new passages to the literary memory. The transmission of Eusebius' letter does not reveal its relation to his works and whether the public of the other accounts had access to it. Athanasius' use of it in his treatise on the Nicene faith and, especially, in the Epistula ad Afros, gave it a prominence among those aware of either work. It was, then, prone to circulate, possibly as a stand-alone piece, and be received as an authoritative text, as a writing to be agonistically analysed and eventually refuted. Sabinus, Gelasius, Scorates and Cyril exemplify the wide range of engagement with it, with impact on the transmitted text.

Athanasius' evaluation of Eusebius' letter imparted on it a finality it never could have had as mere physical written evidence of an individual discourse, not supported by further guarantees of its use and effectiveness. The reception of Athanasius and the consolidation of his authority in most Christianities lent trustworthiness to Eusebius' letter and credibility to its account. It set a precedent for letters on participation at synods to be addressed to dioceses, offering a token of pastoral concern, acknowledgment, and communication of collective and imperially endorsed faith and piety. 
The self-effacing discourse can easily seem a notion of individualisation focused on the self, so that the authorship of theological arguments and texts would now be characterised as creativity, in conflict with classical notions of authorship which still prevailed in Late Antiquity. The fact that it was plausible that they sent the letters to their dioceses indicates the theological and disciplinary individualisation of the lived Christian religion in the dioceses by which the local population or significant groups could react against their bishops if they seemed to fail to protect their interests or were accused of apostasy. The reception of the texts imputed a marked degree of agency to the authorial voice in the letters of Eusebius and Cyril (Ando 2006, 127). Historicising the authorial personae creates a focus on the individual which usually exaggerates the past reality. Actual agency is rather to be seen in the authoring of a persuasive narrative of the past which succeeds in establishing traditions and the reputation of the characters.

Eusebius of Caesarea's Epistula ad Caesarienses and Cyril's Epistula ad clerum populumque Alexandrinum are representative of the two main material narrative processes of religious individualisation, namely, quotation and compilation. An author or an editor created a narrative by the material appropriation of the narrative culture (Urban 1996). The arguments aimed to avoid rejection grounded on accusations of siding with condemned beliefs, or prevent impediments to return to or stay in their sees because of collective actions motivated by local cultural and religious interests. The self-effacing effort of a bishop to assert authority in his diocese or to persuade fellow bishops included merging in an imprecise collective notion of church, of company of the fathers, of assembled bishops, and was concomitant to an effort for distinctiveness from religious authorities who in his view expounded a deviant faith. Socrates Scholasticus' criticism of Eusebius shows that this effort was central to his rhetorical presentation of the data and arguments. Once 'improved' through the lens of Athanasius, Rufinus, Sozomen, Theodoret, and others, Eusebius' narrative became history.

\section{References}

Abramowski, Luise. 1982. 'Dionys von Rom († 268) und Dionys von Alexandrien († 264/5) in den arianischen Streitigkeiten des 4. Jahrhunderts', Zeitschrift für Kirchengeschichte 93. 240-72.

Allen, Pauline and Bronwen Neil. 2013. Crisis Management in Late Antiquity (410-590 CE): A Survey of the Evidence from Episcopal Letters. Supplements to Vigiliae Christianae 121. Leiden/Boston: Brill.

Amirav, Hagit. 2015. Authority and Performance: Sociological Perspectives on the Council of Chalcedon (AD 451). Hypomnemata 199. Göttingen: Vandenhoeck \& Ruprecht. 
Ando, Clifford. 2006. 'Religion and ius publicum'. In Religion and Law in Classical and Christian Rome, eds. idem and Jörg Rüpke. Potsdamer Altertumswissenschaftliche Beiträge 15, Stuttgart: Franz Steiner. 126-45.

Ando, Clifford. 2010. 'The Ontology of Religious Institutions', History of Religions 50.1. 54-79.

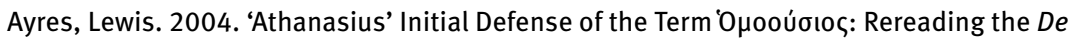
Decretis', Journal of Early Christian Studies 12.3. 337-59.

Ayres, Lewis. 2007. 'Majority Rules', First Things 178. 45.

Barnes, Timothy D. 2007. 'The New Critical Edition of Athanasius' Defence before Constantius', Zeitschrift für Antikes Christentum 11.2. 378-401.

Barnes, Timothy D. 2011. Constantine: Dynasty, Religion, and Power in the Later Roman Empire. Chichester/Malden, MA: Wiley-Blackwell.

Belayche, Nicole. 2013. 'Individualization and Religious Rhetoric in Imperial Anatolia'. In The Individual in the Religions of the Ancient Mediterranean, ed. Jörg Rüpke, Oxford: Oxford University Press. 243-66.

Berg, Robbert (Rudolphus) M. van den. 2001. Proclus' hymns: essays, translations, commentary. Philosophia antiqua 90. Leiden/Boston: Brill.

Bergjan, Silke-Petra. 2017. 'Athanasius von Alexandrien: Aristoteles-Lektüre im Nachgang zu den Synoden von Rimini und Seleukia'. In Kirche und Kaiser in Antike und Spätantike, eds. Uta Heil and Jörg Ulrich. Arbeiten zur Kirchengeschichte 136, Berlin/ Boston: De Gruyter. 131-52.

Bevan, George A. 2016. The New Judas: The Case of Nestorius in Ecclesiastical Politics, 428-451 CE. Late Antique History and Religion 13. Leuven: Peeters.

Blaudeau, Philippe. 2012. 'Sources conciliaires et histoire de l'Empire Romain: une lecture de Fergus Millar'. In Rome, a city and its empire in perspective: the impact of the Roman world through Fergus Millar's research = Rome, une cité impériale en jeu: l'impact du monde romain selon Fergus Millar, ed. Stéphane Benoist, Leiden/Boston: Brill. 139-54.

Bleckmann, Bruno and Horst Schneider (eds). 2007. Eusebius. De vita Constantini = Über das Leben Konstantins. Fontes Christiani 83. Turnhout: Brepols.

Bouffartigue, Jean, Annick Martin and Pierre Canivet (eds). 2006. Théodoret de Cyr. Histoire ecclésiastique I. Sources chrétiennes 501. Paris: Éditions du Cerf.

Bowes, Kimberly D. 2007. “'Christianization” and the Rural Home', Journal of Early Christian Studies 15.2.143-70.

Boyarin, Daniel. 2000. 'A Tale of Two Synods: Nicaea, Yavneh, and Rabbinic Ecclesiology', Exemplaria 12.1. 21-62.

Börm, Henning. 2015. 'Antimonarchic Discourse in Antiquity: A Very Short Introduction'. In Antimonarchic Discourse in Antiquity, eds. idem and Wolfgang Havener. Studies in ancient monarchies 3, Stuttgart: Franz Steiner. 9-24.

Brennecke, Hanns Christof. 2011. "Patristik” oder "altchristliche Literaturwissenschaft”? Eine historische Leitwissenschaft der protestantischen Theologie in Deutschland am Beginn des 20. Jahrhunderts', Zeitschrift für Antikes Christentum 15.1. 7-46.

Brennecke, Hanns Christof., Uta Heil and Annette von Stockhausen (eds). 2006. Athanasius Werke. Zweiter Band, Die Apologien: Lieferung 8: Apologia ad Constantium, epistula ad Joannem et Antiochum, epistula ad Palladium, epistula ad Dracontium, epistula ad Afros, tomus ad Antiochenos, epistula ad Jovianum, epistula Joviani ad Athanasium, petitiones Arianorum. Athanasius Werke 2.8. Berlin/New York: De Gruyter.

Brennecke, Hanns Christof. et al. (eds). 2007. Dokumente zur Geschichte des arianischen Streites: Lieferung 3: bis zur Ekthesis Makrostichos. Athanasius Werke 3.1.3. Berlin: De Gruyter. 
Cameron, Averil and Stuart George Hall (eds). 1999. Eusebius. Life of Constantine. Oxford: Clarendon Press.

Campenhausen, Hans Freiherr V. 1976. 'Das Bekenntnis Eusebs von Caesarea (Nicaea 325)', Zeitschrift für die Neutestamentliche Wissenschaft und die Kunde der Älteren Kirche 67.1. 123-39.

Carotenuto, Erica. 2002. 'Six Constantinian documents (Eus. H.E. 10, 5-7)', Vigiliae Christianae 56.1. 56-74.

Cassin, Matthieu. 2015. 'Extraire pour réfuter. Pratiques de la fin du IV siècle après Jésus Christ'. In Lire en extraits. Lecture et production des textes, de l'Antiquité à la fin du Moyen Âge, ed. Sébastien Morlet, Paris: Presses de l'Université Paris-Sorbonne. 239-57.

Chadwick, Henry. 1972. 'The Origin of the Title “Oecumenical Council”', Journal of Theological Studies 23. 132-5.

Corcoran, Simon. $2000^{2}$. The empire of the Tetrarchs: imperial pronouncements and government, $A D$ 284-324. Oxford: Clarendon Press.

Crawford, Matthew R. 2013. 'On the Diversity and Influence of the Eusebian Alliance: The Case of Theodore of Heraclea', The Journal of Ecclesiastical History 64.2. 227-57.

DelCogliano, Mark. 2011a. 'George of Laodicea: A Historical Reassessment', The Journal of Ecclesiastical History 62.4. 667-92.

DelCogliano, Mark. 2011b. 'The Promotion of the Constantinian Agenda in Eusebius of Caesarea's On The Feast Of Pascha'. In Reconsidering Eusebius: Collected Papers on Literary, Historical, and Theological Issues, eds. Sabrina Inowlocki and Claudio Zamagni, Leiden/Boston: Brill. 39-68.

DelCogliano, Mark. 2015. 'Asterius in Athanasius' Catalogues of Arian views', The Journal of Theological Studies 66.2. 625-50.

Diefenbach, Steffen. 2012. 'Constantius II. und die "Reichskirche” - ein Beitrag zum Verhältnis von kaiserlicher Kirchenpolitik und politischer Integration im 4. Jh.', Millennium 9.1. 59-122.

Dijkstra, Jitse Harm Fokke. 2015. 'Religious Violence in Late Antique Egypt Reconsidered: The Cases of Alexandria, Panopolis and Philae', Journal of early Christian history 5. 24-48.

Donner, Fred M. 2006. 'Hagarism: The Making of the Islamic World (Book Review)', Middle East Studies Association Bulletin 40.2. 197-9.

Drake, Harold A. 2013. 'Monotheism and Violence', Journal of Late Antiquity 6.2. 251-63.

Drake, Harold A. 2014. 'Nicaea to Tyre (325-335): the bumpy road to a Christian Empire', Antiquité Tardive 22. 43-52.

Drecoll, Volker H. 2011. 'Remarks on Christopher Beeley, Gregory of Nazianzus on the Trinity and the Knowledge of God. In Your light we shall see light', Scottish Journal of Theology 64.4. 456-73.

Dunn, Geoffrey D. 2015a. 'Collectio Corbeiensis, Collectio Pithouensis and the earliest collections of papal letters'. In Collecting Early Christian Letters: From the Apostle Paul to Late Antiquity, eds. Bronwen Neil and Pauline Allen. Legal Documents in Ancient Societies 4, Cambridge: Cambridge University Press. 175-205.

Dunn, Geoffrey D. 2015b. 'Innocent I on Heretics and Schismatics as Shaping Christian Identity'. In Christians Shaping Identity from the Roman Empire to Byzantium: Studies Inspired by Pauline Allen, eds. idem and Wendy Mayer. Supplements to Vigiliae Christianae 132, Leiden/Boston: Brill. 266-90.

Elm, Susanna. 2015. ‘Gregory of Nazianzus: Mediation between Individual and Community'. In Group Identity and Religious Individuality in Late Antiquity, eds. Éric Rebillard and Jörg Rüpke, Washington, DC: Catholic University of America Press. 89-107. 
Feige, Gerhard. 1992. 'Markell von Ankyra und das Konzil von Nizäa (325)'. In Denkender Glaube in Geschichte und Gegenwart: Festschrift aus Anlass der Gründung der Universität Erfurt vor 600 Jahren und aus Anlass des 40jährigen Bestehens des PhilosophischTheologischen Studiums Erfurt, eds. Wilhelm Ernst and Konrad Feiereis. Erfurter theologische Studien 63, Leipzig: Benno Verlag. 277-96.

Flower, Richard. 2013. Emperors and Bishops in Late Roman Invective. Cambridge: Cambridge University Press.

Fraisse-Coué, Christianne. 1995. 'Le débat théologique au temps de Théodose II: Nestorius'. In Naissance d'une chrétienté (250-430), eds. Charles Pietri, Luce Pietri and Jaques Biarne. Histoire du christianisme des origines à nos jours 2, Paris: Desclée. 499-550.

Frenkel, Luise M. 2015. Theodotus of Ancyra's homilies and the Council of Ephesus (431). Studia Patristica Supplements 4. Leuven: Peeters.

Frenkel, Luise M. 2017. 'Procedural Similarities between Fourth and Fifth-Century Christian Synods and the Roman Senates: Myth, Politics or Cultural Identity?' In Studia Patristica XCII: Papers presented at the Seventeenth International Conference on Patristic Studies held in Oxford 2015. Volume 18: Liturgica and Tractatus symboli - Orientalia - Critica et Philologica - Historica, ed. Markus Vinzent, Leuven: Peeters. 293-302.

Gemeinhardt, Peter (ed). 2011. Athanasius Handbuch. Tübingen: Mohr Siebeck.

Gordon, Richard L. 2015. 'Negotiating the Temple-Script: Women's Narratives among the “Confession-Texts” of Western Asia Minor', Religion in the Roman Empire 2.2. 227-55.

Grafton, Anthony and Megan Hale Williams. 2006. Christianity and the Transformation of the Book: Origen, Eusebius, and the Library of Caesarea. Cambridge, MA: Harvard University Press.

Graumann, Thomas. 2002. Die Kirche der Väter: Vätertheologie und Väterbeweis in den Kirchen des Ostens bis zum Konzil von Ephesus (431). Beiträge zur historischen Theologie 118. Tübingen: Mohr Siebeck.

Graumann, Thomas. 2003a. 'Kirchliche Identität und bischöfliche Selbstinszenierung. Der Rückgriff auf "Athanasius" bei der Überwindung des nachephesinischen Schismas und in Kyrills Propaganda'. In Literarische Konstituierung von Identifikationsfiguren in der Antike, eds. Barbara Aland, Johannes Hahn and Christian Ronning. Studien und Texte zu Antike und Christentum 16. Tübingen: Mohr Siebeck. 195-213.

Graumann, Thomas. 2003b. 'Origenes - ein Kirchenvater?: Vom Umgang mit dem origeneischen Erbe im frühen 4. Jahrhundert'. In Origeniana octava: Origen and the Alexandrian Tradition 2, ed. Lorenzo Perrone, Leuven: Peeters. 877-88.

Graumann, Thomas. 2009. “'Reading” the First Council of Ephesus (431)'. In Chalcedon in context: church councils 400-700, eds. Richard Price and Mary Whitby. Translated texts for historians. Contexts 1, Liverpool: Liverpool University Press. 27-44.

Graumann, Thomas. 2017a. 'Kaiserliche Selbstdarstellung und kirchenpolitisches Handeln: Ein Beitrag zur Frage nach Kirche und Reich unter Theodosius Il'. In Kirche und Kaiser in Antike und Spätantike, eds. Uta Heil and Jörg Ulrich. Arbeiten zur Kirchengeschichte 136, Berlin/ Boston: De Gruyter. 268-304.

Graumann, Thomas. 2017b. 'Theologische Diskussion und Entscheidung auf Synoden: Verfahrensformen und -erwartungen'. In Die Synoden im trinitarischen Streit = The Synods in the Trinitarian Dispute, eds. Uta Heil and Annette von Stockhausen. Texte und Untersuchungen zur Geschichte der altchristlichen Literatur 177, Berlin/Boston: De Gruyter. 51-82.

Gwynn, David M. 2007. The Eusebians: the polemic of Athanasius of Alexandria and the construction of the "Arian controversy". Oxford/New York: Oxford University Press. 
Gwynn, David M. 2010. 'Archaeology and the "Arian controversy” in the fourth century'. In Religious Diversity in Late Antiquity, eds. idem and Susanne Bangert. Late Antique Archaeology 6, Leiden/Boston: Brill. 229-63.

Gwynn, David M. 2013. 'Athanasius of Alexandria in Greek and Coptic Historical Tradition', Journal of Coptic Studies 15.54. 43-54.

Hansen, Günther Christian (ed.). 1995. Sokrates. Kirchengeschichte. Griechischen christlichen Schriftsteller der ersten Jahrhunderte n. F. 1. Berlin: Akademie-Verlag.

Hauschild, Wolf-Dieter. 1970. 'Die Antinizänische Synodalaktensammlung des Sabinus von Heraklea', Vigiliae Christianae 24.2.105-126.

Heikel, Ivar A. (ed). 1913. Athanasius. Die Demonstratio Evangelica. Die griechischen christlichen Schriftsteller der ersten Jahrhunderte 23. Berlin/Boston: De Gruyter.

Heil, Uta (ed). 1999. Athanasius von Alexandrien, De sententia Dionysii. Patristische Texte und Studien 52. Berlin/Boston: De Gruyter.

Heil, Uta. 2010. 'Markell von Ancyra und das Romanum'. In Von Arius zum Athanasianum. Studien zur Edition der “Athanasius Werke”, eds. Annette von Stockhausen and Hanns Christof Brennecke. Texte und Untersuchungen zur Geschichte der altchristlichen Literatur 164, Berlin/Boston: De Gruyter. 85-105.

Hezser, Catherine. 2005. 'Towards the Study of Jewish Popular Culture in Roman Palestine'. In 'The words of a wise man's mouth are gracious' (Qoh 10,12): Festschrift for Günter Stemberger on the occasion of his 65th birthday, ed. Mauro Perani. Studia Judaica 32, Berlin: De Gruyter. 267-98.

Higgins, Martin J. 1966. 'Two Notes'. In Polychronion: Festschrift Franz Dölger zum 75. Geburtstag, ed. Peter Wirth. Corpus der griechischen Urkunden des Mittelalters und der neueren Zeit. Reihe D: Beiheft: Forschungen zur griechischen Diplomatik und Geschichte 1, Heidelberg: Winter. 238-43.

Hillner, Julia. 2015. Prison, Punishment and Penance in Late Antiquity. Cambridge: Cambridge University Press.

Humfress, Caroline. 2013. 'Law's empire: Roman universalism and legal practice'. In New Frontiers: Law and Society in the Roman World, ed. Paul J. du Plessis, Edinburgh: Edinburgh University Press. 73-101.

Humfress, Caroline. 2014. 'Institutionalisation between Theory and Practice: Comparative Approaches to Medieval Islamic and Late Roman Law'. In Diverging paths? The shapes of power and institutions in medieval Christendom and Islam, eds. John Hudson and Ana Rodríguez López. Medieval Mediterranean 101, Leiden/Boston: Brill. 16-29.

Humphries, Mark. 2015. 'Emperors, Usurpers, and the City of Rome: Performing Power from Diocletian to Theodosius'. In Contested Monarchy: Integrating the Roman Empire in the Fourth Century AD, ed. Johannes Wienand, Oxford: Oxford University Press. 151-68.

Inowlocki, Sabrina. 2011. 'Eusebius' construction of a Christian culture in an apologetic context: reading the Praeparatio evangelica as a library'. In Reconsidering Eusebius: Collected Papers on Literary, Historical, and Theological Issues, eds. idem and Claudio Zamagni. Supplements to Vigiliae Christianae 107. Leiden/Boston: Brill. 199-223.

Johnson, Aaron P. 2014. Eusebius. Understanding classics. London: I.B. Tauris.

Johnson, Scott F. 2006. 'Eusebius' Praeparatio Evangelica as Literary Experiment'. In Greek literature in late antiquity: dynamism, didacticism, classicism, ed. idem, Aldershot: Ashgate. 67-89.

Kahlos, Maijastina. 2014. 'Ditches of destruction - Cyril of Alexandria and the rhetoric of public security', Byzantinische Zeitschrift 107.2. 11-33. 
Kaldellis, Anthony. 2015. The Byzantine Republic: People and Power in New Rome. Cambridge, MA: Harvard University Press.

Kannengiesser, Charles. 2006. 'The Dating of Athanasius' Double Apology and Three Treatises Against the Arians', Zeitschrift für Antikes Christentum 10.1.19-33.

Kinzig, Wolfram. 2017. Neue Texte und Studien zu den antiken und frühmittelalterlichen Glaubensbekenntnissen. Arbeiten zur Kirchengeschichte 132. Berlin/Boston: De Gruyter.

Klostermann, Erich and Günther Christian Hansen (eds). 1971². Eusebius Werke IV (GCS). Gegen Marcell. Über die kirchliche Theologie. Die Fragmente Marcells. Die Griechischen christlichen Schriftsteller der ersten Jahrhunderte 14. Berlin: Akademie-Verlag.

Kristensen, Troels M. 2016. 'Maxentius' Head and the Rituals of Civil War'. In Civil War in Ancient Greece and Rome Contexts of Disintegration and Reintegration, eds. Henning Börm, Marco Mattheis and Johannes Wienand. Heidelberger Althistorische Beiträge und Epigraphische Studien 58, Stuttgart: Franz Steiner. 224-46.

Lieu, Judith M. 2016. 'Letters and the Topography of Early Christianity', New Testament studies 62.2.167-82.

Martin, Annick. 1997. 'Athanase d'Alexandrie, l'Église et les moines. A propos de la Vie d'Antoine', Revue des sciences religieuses 71.2.171-88.

Mattheis, Marco. 2014. Der Kampf ums Ritual: Diskurs und Praxis traditioneller Rituale in der Spätantike. Geschichte 4. Düsseldorf: Wellem.

Mayer, Wendy and Bronwen Neil. 2013. 'Religious Conflict: Definitions, Problems and Theoretical Approaches'. In Religious conflict from early Christianity to the rise of Islam, eds. idem and idem. Arbeiten zur Kirchengeschichte 121, Berlin/Boston: De Gruyter. 1-19.

McCarthy Spoerl, Kelley. 2006. 'Athanasius and the Anti-Marcellan Controversy', Zeitschrift für Antikes Christentum 10.1. 34-55.

McKitterick, Rosamond. 2016. 'The Papacy and Byzantium in the seventh- and early eighthcentury Sections of the Liber Pontificalis', Papers of the British School at Rome 84. 241-73.

McLynn, Neil. 1996. 'From Palladius to Maximinus: Passing the Arian Torch', Journal of Early Christian Studies 4.4. 477-93.

Meeder, Sven. 2015. 'Biblical past and canonical present: the case of the Collectio 400 capitulorum'. In The resources of the past in early medieval Europe, eds. Clemens Gantner, Rosamond McKitterick and idem, Cambridge: Cambridge University Press.

Meier, Mischa. 2011. “"Ein dogmatischer Streit” - Eduard Schwartz (1858-1940) und die “Reichskonzilien” in der Spätantike', Zeitschrift für Antikes Christentum 15.1. 124-39.

Millar, Fergus. 2009. 'Christian Monasticism in Roman Arabia at the Birth of Mahomet', Semitica et Classica 2. 97-115.

Morales, Antonio J. 2017. 'From Voice to Papyrus to Wall: Verschriftung and Verschriftlichung in the Old Kingdom Pyramid Texts'. In Understanding Material Text Cultures: A Multidisciplinary View, ed. Markus Hilgert. Materiale Textkulturen 9, Berlin/Boston: De Gruyter. 69-130.

Morales, Xavier. 2006. La théologie trinitaire d'Athanase d'Alexandrie. Collection des études augustiniennes. Série Antiquité 180. Paris: Institut d'études augustiniennes.

Noethlichs, Karl Leo. 2006. 'Revolution from the top?: "Orthodoxy" and the persecution of heretics in imperial legislation from Constantine to Justinian'. In Religion and Law in CLassical and Christian Rome, eds. Clifford Ando and Jörg Rüpke. Potsdamer altertumswissenschaftliche Beiträge 15, Stuttgart: Franz Steiner. 115-25.

Oesterreicher, Wulf. 2013. 'Pluralisierung der Diskurse: Funktionales Diffundieren, diskurspragmatische Instabilität und "Plagiate" in hispanoamerikanischen Texten des 
16. Jahrhunderts'. In Die Frühe Neuzeit. Revisionen einer Epoche, eds. Andreas Höfele, Jan-Dirk Müller and idem. Pluralisierung \& Autorität 40, Berlin/Boston: De Gruyter. 113-62.

Opitz, Hans-Georg (ed). 1934. Athanasius Werke. Dritter Band. Erster Teil. Lieferung 2: Kaiser Konstantins Schreiben zur Einberufung der nicänischen Synode - Brief Kaiser Konstantins an Arius und Genossen. Berlin/Boston: De Gruyter.

Opitz, Hans-Georg (ed). 1935a. Athanasius Werke. Zweiter Band, Die Apologien: Lieferung 1: De decretis Nicaenae synodi 1,5 - 40,24. Berlin/Boston: De Gruyter.

Opitz, Hans-Georg (ed). 1935b. Athanasius Werke. Zweiter Band, Die Apologien: Lieferung 2: De decretis Nicaenae synodi 40,24 - Apologia de fuga sua 18,3. Berlin/Boston: De Gruyter. Opitz, Hans-Georg. 1935c. Untersuchungen zur Überlieferung der Schriften des Athanasius. Arbeiten zur Kirchengeschichte 23. Berlin/Boston: De Gruyter.

Otto, Bernd-Christian. 2017. 'Magic and Religious Individualization: On the construction and deconstruction of analytical categories in the Study of Religion', Historia Religionum 9. 29-52.

Penland, Elizabeth C. 2013. 'The History of the Caesarean Present: Eusebius and Narratives of Origen'. In Eusebius of Caesarea: Tradition and Innovations, eds. Aaron P. Johnson and Jeremy M. Schott. Hellenic studies 60, Washington, DC: Center for Hellenic Studies. 83-95.

Pfeilschifter, Rene. 2013. Der Kaiser und Konstantinopel: Kommunikation und Konfliktaustrag in einer spätantiken Metropole. Millennium-Studien 44. Berlin/Boston: De Gruyter.

Piepenbrink, Karen. 2014. 'Zur Selbstrepräsentation von Bischöfen des 3. und 4. Jahrhunderts in verbaler Kommunikation', Millennium 11.1. 39-68.

Quiroga Puertas, Alberto J. 2015. 'The Literary Connoisseur. Socrates Scholasticus on Rhetoric, Literature and Religious Orthodoxy', Vigiliae Christianae 69.2.109-22.

Radde-Gallwitz, Andrew. 2017. 'Private Creeds and their Troubled Authors', Journal of Early Christian Studies 25.1. 464-90.

Ramelli, Ilaria L.E. 2011. 'Origen's Anti-Subordinationism and its Heritage in the Nicene and Cappadocian Line', Vigiliae Christianae 65.1. 21-49.

Rammelt, Claudia. 2013. 'Christologische Positionierung als religiöses Alltagsgeschäft in Edessa?'. In Religiöser Alltag in der Spätantike, eds. Peter Eich and Eike Faber. Potsdamer Altertumswissenschaftliche Beiträge 44, Stuttgart: Franz Steiner. 127-44.

Rizzi, Marco. 2013. 'Eusebius on Constantine and Nicaea: Intentions and Omissions', Annali di Scienze Religiose 6. 209-23.

Schor, Adam M. 2015. 'The letters of Theodoret of Cyrrhus'. In Collecting early Christian letters: from the apostle Paul to late antiquity, eds. Bronwen Neil and Pauline Allen. Legal Documents in Ancient Societies 4, Cambridge: Cambridge University Press. 154-72.

Schwartz, Eduard (ed). 1914. Acta conciliorum oecumenicorum - iussu atque mandato Societatis Scientiarum Argentoratensis edidit Eduardus Schwartz [continuauit Johannes Straub]. Berlin/Boston: De Gruyter.

Shepardson, Christine. 2008. Anti-Judaism and Christian Orthodoxy: Ephrem's Hymns in Fourth-Century Syria. Washington, D.C.: Catholic University of America Press.

Sizgorich, Thomas. 2009. Violence and Belief in Late Antiquity: Militant Devotion in Christianity and Islam. Philadelphia: University of Pennsylvania Press.

Stockhausen, Annette von (ed). 2002. Athanasius von Alexandrien. Epistula ad Afros. Patristische Texte und Studien 56. Berlin/Boston: De Gruyter.

Stockhausen, Annette von. 2015. 'Die Edition der Konzilsakten und das Problem der Sammlungen. Editionsphilologische Überlegungen anhand der Acta Conciliorum 
Oecumenicorum III'. In Crux interpretum: Ein kritischer Rückblick auf das Werk von Eduard Schwartz, eds. Uta Heil and idem. Texte und Untersuchungen zur Geschichte der altchristlichen Literatur 177, Berlin/Boston: De Gruyter. 129-44.

Stroumsa, Guy G. 2016. 'Religious memory, between orality and writing', Memory Studies 9.3. 332-40.

Strutwolf, Holger. 1999. Die Trinitätstheologie und Christologie des Euseb von Caesarea: eine dogmengeschichtliche Untersuchung seiner Platonismusrezeption und Wirkungsgeschichte. Forschungen zur Kirchen- und Dogmengeschichte 72. Göttingen: Vandenhoeck \& Ruprecht.

Testa, Rita L. 2013. “'Inter christianos etiam gentilitatis cultores sed et veteris legis studiosi audientiae sint adhibendi": The Impact of Theological Controversies on the Intellectual Life of Late Antiquity', Adamantius 19. 276-89.

Testa, Rita L. 2014. 'Constantinian's centenaries and the influence of the contemporary'. In L'Orient Chrétien de Constantin et d'Eusèbe de Césarée, ed. idem. Antiquité tardive 22, Turnhout: Brepols. 13-26.

Tetz, Martin et al. (eds). 1996. Athanasius Werke. Erster Band, Die Dogmatischen Schriften: Lieferung 1: Epistula ad episcopos Aegypti et Libyae. Athanasius Werke 1.1.1. Berlin/New York: De Gruyter.

Urban, Greg. 1996. 'Entextualization, Replication, and Power'. In Natural histories of discourse, eds. Michael Silverstein and idem, Chicago: Chicago University Press. 21-44.

van Loon, Hans. 2014. 'Violence in the Early Years of Cyril of Alexandria's Episcopate'. In Violence in ancient Christianity: victims and perpetrators, eds. Albert C. Geljon and Riemer Roukema. Supplements to Vigiliae Christianae 125, Leiden/Boston: Brill. 108-31.

van Nuffelen, Peter. 2004. Un héritage de paix et de piété: étude sur les histoires ecclésiastiques de Socrate et de Sozomène. Orientalia Lovaniensia analecta 142. Leuven: Peeters.

Verdoner, Marie. 2011. Narrated Reality: the 'Historia ecclesiastica' of Eusebius of Caesarea. Early Christianity in the context of antiquity 9. Frankfurt am Main: Peter Lang.

Vinzent, Markus. 1999. 'Die Entstehung des „Römischen Glaubensbekenntnisses“'. In: Tauffragen und Bekenntnis: Studien zur sogenannten „Traditio Apostolica“ zu den „Interrogationes de fide“ und zum „Römischen Glaubensbekenntnis“, eds. Wolfram Kinzig, Christoph Markschies and idem. Arbeiten zur Kirchengeschichte 74. Berlin: De Gruyter. 185-410.

Vinzent, Markus and Kelley McCarthy Spoerl (eds). 2017. Eusebius of Caesarea, Against Marcellus and On Ecclesiastical Theology. The Fathers of the Church 135. Washington, D.C.: Catholic University of America Press.

Wallraff, Martin. 1997. Der Kirchenhistoriker Sokrates: Untersuchungen zu Geschichtsdarstellung, Methode und Person. Forschungen zur Kirchen- und Dogmengeschichte 68. Göttingen: Vandenhoeck \& Ruprecht.

Weckwerth, Andreas. 2010. Ablauf, Organisation und Selbstverständnis westlicher antiker Synoden im Spiegel ihrer Akten. Jahrbuch für Antike und Christentum. Ergänzungsband, Kleine Reihe 5. Münster: Aschendorff.

Wienand, Johannes. 2012. Der Kaiser als Sieger: Metamorphosen triumphaler Herrschaft unter Constantin I. Berlin: Akademie Verlag.

Winkelmann, Friedhelm, Luce Pietri and Marie-Joseph Rondeau (eds). 2013. Eusèbe de Césarée. Vie de Constantin. Sources chrétiennes 559. Paris: Éditions du Cerf. 
Wipszycka, Ewa. 2015. The Alexandrian Church: People and Institutions. Journal of Juristic Papyrology. Supplement 25. Warsaw: Journal of Juristic Papyrology.

Young-Evans, G. I. 2016. 'The Devil is in the Detail: The Origins of Heresies in Socrates's "Historia Ecclesiastica”, The Journal of Ecclesiastical History 67.1.1-22.

Zamagni, Claudio. 2011. 'Eusebius' Exegesis between Alexandria and Antioch: Being a Scholar in Caesarea (a Test Case from Questions to Stephanos I)'. In Reconsidering Eusebius: Collected Papers on Literary, Historical, and Theological Issues, eds. Sabrina Inowlocki and idem. Supplements to Vigiliae Christianae 107, Leiden/Boston: Brill. 151-76. 